\title{
IMPLEMENTASI NILAI-NILAI BUDAYA, SOSIAL, DAN LINGKUNGAN PENGEMBANGAN DESA WISATA DI PROVINSI YOGYAKARTA
}

\author{
Joko Tri Haryanto \\ Unit Kebijakan Fiskal Kementerian Keuangan \\ Email: djohar78@gmail.com
}

\begin{abstract}
Although giving a huge benefit to the developing of social welfare in the world, tourism development has also often ces of the environmental damage, when especially requiring for infrastructure development. However, along with increased awareness of the importance of environmental functions, isustainable tourism or usually called ecotourism has developed with many different kinds. Yogyakarta, as one of tourist destinations in Indonesia, has developed cultural values, social, and environment based ecotourism in the form of Tourism Village. This kind of Tourism Village has not unfortunately, identified and used social, cultural, and environmental values as among the main attractions. for this reason this paper is written to provide guidance for implementing the cultural values, social, and environment based eco-tourism in order to develop the Tourism Village.
\end{abstract}

Keyword: Ecotourism, Sustainable Tourism, Tourism Village, Ecotourism Pillars

\begin{abstract}
ABSTRAK
Meskipun memberikan manfaat yang besar bagi perkembangan kesejahteraan masyarakat di dunia, pembangunan pariwisata juga sering disebut sebagai salah satu sumber kerusakan lingkungan utama, ketika pembangunan pariwisata tersebut membutuhkan penyediaan infrastruktur yang harus merusak alam. Akan tetapi,seiring dengan peningkatan kesadaran akan pentingnya fungsi lingkungan, berkembang gerakan pariwisata berkelanjutan atau diistilahkan ekowisata. Yogyakarta sebagai salah satu daerah tujuan wisata juga mengembangkan ekowisata yang berbasis nilai-nilai budaya, sosial, dan lingkungan berguna untuk dijadikan ragam atraksi utama. Untuk itulah tulisan ini disusun sebagai guidance bagi Desa Wisata dalam mengimplementasikan nilai-nilai budaya, sosial, dan lingkungan dalam mengembangkan Desa Wisata.
\end{abstract}

Kata Kunci: Ecotourism, Sustainable Tourism, Desa Wisata, Ecotourism Pillars 


\section{PENGANTAR}

Undang-undang Nomor 10 Tahun 2009 tentang Kepariwisataan menyebutkan bahwa pariwisata didefinisikan "berbagai macam kegiatan wisata dan didukung berbagai fasilitas serta layanan yang disediakan oleh masyarakat, pengusaha, Pemerintah dan Pemerintah Daerah". Sedangkan wisata itu sendiri didefinisikan sebagai "kegiatan perjalanan yang dilakukan oleh seseorang atau sekelompok orang dengan mengunjungi tempat tertentu untuk tujuan rekreasi, pengembangan pribadi, atau mempelajari keunikan daya tarik wisata yang dikunjungi dalam jangka waktu sementara".

Di samping peningkatan jumlah kunjungan tamu asing, faktor lain yang juga sangat berpengaruh terhadap industri pariwisata Indonesia adalah pergerakan wisatawan nusantara (wisnus). Disadari bahwa peranan wisnus merupakan yang terbesar dalam menciptakan dampak ekonomi, makaKementerianKebudayaandan Pariwisata semakin gencar untuk mengajak penduduk Indonesia melakukan perjalanan atau wisata di dalam negeri. Dengan slogan "Ayo Jelajahi Nusantara", "Kenali Negerimu, Cintai Negerimu" diharapkan semakin banyak penduduk Indonesia yang ingin mengetahui lebih banyak tentang negerinya sendiri (NESPARNAS, 2009).

Meskipun memberikan manfaat yang besar bagi perkembangan kesejahteraan masyarakat di dunia, pembangunan pariwisata juga sering disebut sebagai salah satu sumber kerusakan lingkungan utama, ketika pembangunan pariwisata tersebut membutuhkan penyediaan infrastruktur yang harus merusak alam sebagaimana yang disebutkan dalam laporan World Tourism Organization tahun 1996.

Dalam perkembangannya, seiring dengan tuntutan terciptanya pembangunan yang berkelanjutan serta kegiatan pariwisata yang ramah lingkungan, negara-negara yang memiliki kekayaan alam dan budaya mulai mengembangkan jenis pariwisata ekologis atau yang lebih dikenal sebagai ekowisata.
Ekowisata ini lebih dari sekedar kelompok pecinta alam yang berdedikasi, sebagai gabungan berbagai kepentingan yang muncul dari keperdulian terhadap masalah sosial, ekonomi, dan lingkungan. Bagaimana membuat devisa masuk kembali sehingga konservasi alam dapat membiayai dirinya sendiri merupakan inti dari cabang baru ilmu ekonomi hijau pembangunan berkelanjutan ini (Western, 1999;2-3).

Pembangunan pariwisata berkelanjutan, seperti disebutkan dalam Piagam Pariwisata Berkelanjutan (1995) adalah pembangunan yang dapat didukung secara ekologis sekaligus layak secara ekonomi, juga adil secara etika, dan sosial terhadap masyarakat. Artinya bahwa pembangunan berkelanjutan adalah upaya terpadu dan terorganisasiuntuk mengembangkan kualitas hidup dengan cara mengatur penyediaan, pengembangan, pemanfaatan, dan pemeliharaan sumber daya secara berkelanjutan.

Sebagai salah satu tujuan wisata utama di Indonesia, Yogyakarta memiliki banyak faktor yang mampu menarik datangnya wisatawan baik domestik maupun mancanegara. Faktor keanekaragaman atraksi dan daerah tujuan wisata, di mana terdapat lebih dari 50 tempat tujuan wisata, kemudian faktor atribut budaya, sejarah, dan alam yang menjadi ciri khas utama wisata Yogyakarta serta memberikan identitas yang unik terhadap pariwisata Yogyakarta. Berbagai atribut tersebut dapat menggambarkan pariwisata Yogyakarta secara keseluruhan (Rahajeng dalam Haryanto, 2012).

Secara keseluruhan potensi pariwisata di Yogyakarta dibagi menjadi potensi wisata alam berupa pegunungan yang masih aktif di bagian utara, barat laut dan tenggara (Merapi, Menoreh dan Sewu). Beberapa pegunungan ini memiliki potensi ekowisata yang sangat menarik serta memiliki keindahan pemandangan beserta keanakaragaman flora dan fauna yang membentuk biodiversity yang unik.

Potensi wisata alam lainnya berupa kawasan hutan negara yang tidak terlalu luas yang juga memiliki potensi wisata ekologi misalnya hutan hujan tropis di pegunungan 
lereng Merapi, hutan suksesi primer di dekat puncak Merapi, dan hutan pendidikan dan penelitian di Gunung Kidul. Di luar kawasan hutan terdapat pertanian dan perkebunan yang dapat dikembangkan menjadi wisata agro misalnya wisata agro tanaman Salak Pondoh di Kabupaten Sleman. Pertanian dan perkebunan juga memiliki potensi sistem sosial dengan budaya dan adat istiadat yang menarik bagi wisatawan.

Bagi pakar arkeologi, Yogyakarta sangat menarik karena memiliki sekitar 36 candi atau situs bersejarah. Selain itu Yogyakarta juga memiliki persekitaran yang indah dengan bangunan-bangunan arsitektur tradisional yang masih banyak dijumpai. Kehidupan sosial yang selaras dan serasi antara unsur tradisional dan modern membentuk keharmonisan. Upacara-upacara tradisional masih terpelihara dengan baik hingga kini.

Suasana malam di Yogyakarta yang romantis dengan lampu-lampu hiasnya membuat Yogyakarta menjadi daerah yang menarik untuk dikunjungi tidak hanya sekali, tetapi juga ngangeni (membuat rindu dan ingin datang kembali). Seni dan budaya tradisional seperti musik gamelan dan tarian tradisional mampu mengingatkan siapapun yang melihatnya akan kehidupan masa lampau. Umumnya obyek wisata ini terletak di sekitar Kraton Yogyakarta sebagai pusat kebudayaan Jawa yang merujuk pada budaya Kerajaan Mataram (Rahajeng dalam Haryanto, 2012).

Sejalan dengan meningkatnya gerakan pengembangan ekowisata, Pemerintah Yogyakarta juga serius memajukan beberapa potensi pariwisata yang dapat diaplikasikan menjadi konsep ekowisata, seperti pengembangan ekowisata Kaliadem dan Merapi Eco Adventure yang menawarkan sebuah konsep pariwisata berbasis keindahan alam dan kenyamanan udara Merapi yang dipadukan dengan interaksi masyarakat desa di lereng Merapi berikut kebudayaan yang dimiliki seperti labuhan sesaji untuk Merapi.

Konsep ekowisata lainnya yang dikembangkan adalah konsep ekowisata Kali Code Utara di Kota Yogyakarta. Kali
Code Utara sebagai salah satu anak sungai yang langsung terhubung dengan Merapi, menyimpan potensi ekowisata yang berupa wisata pengelolaan sampah mandiri, Ipal komunal serta wisata trecking di sepanjang Kali Code Utara dengan menikmati keindahan arsitektur kali hasil binaan YB. Mangunwijaya (Karomah, 2007;16-18).

Implementasi dalam pengembangan ekowisata di Provinsi Yogyakarta diwujudkan dalam bentuk Desa Wisata yang tersebar hampir di beberapa wilayah kabupaten dan kota diantaranya Kabupaten Bantul, Kabupaten Sleman, Kabupaten Kulon Progo dan Kabupaten Gunung Kidul. Ada beberapa ekowisata yang sudah relatif maju dan berkembang, tetapi sebagian besar masih membutuhkan dorongan dan perhatian ekstra dari Pemerintah karena memang diharapkan masyarakat menjadi pengelola sekaligus penangungjawab pelaksanaan Desa Wisata tersebut.

Kendala keterbatasan infrastruktur fisik dan dana tentu menjadi permasalahan di beberapa Desa Wisata. Akan tetapi, demikian kendala utama sebetulnya justru terletak dari manajemen pengelolaan Desa Wisata itu sendiri, khususnya implementasi dari aspek budaya, sosial, dan lingkungan dalam pengembangan Desa Wisata. Banyak sekali Desa Wisata yang kesulitan menemukan aspek budaya, sosial, dan lingkungan yang nantinya menjadi keunggulan utama Desa Wisata tersebut dalam menarik wisatawan.

Bentuk implementasi nilai-nilai budaya, sosial, dan lingkungan yang mendukung pengembangan Desa Wisata di Provinsi Yogyakarta sebagai berikut: (1) Nilai-nilai budaya, sosial, dan kearifan lingkungan yang mendukung pengembangan Desa Wisata di Provinsi Yogyakarta. (2) Implementasi nilainilai budaya, sosial dan lingkungan dalam pengembangan Desa Wisata di Provinsi Yogyakarta.

Definisi pariwisata memang tidak dapat persis sama di antara para ahli, hal yang memang jamak terjadi dalam dunia akademis, sebagaimana juga dapat ditemui pada berbagai disiplin ilmu lain. Meskipun ada variasi batasan, ada beberapa komponen 
pokok yang secara umum disepakati di dalam batasan pariwisata yaitu adanya unsur travel, adanya unsur tinggal sementara di tempat yang bukan tempat tinggalnya serta tujuan utamanya bukan untuk mencari penghidupan di tempat yang dituju (Pitana dan Diarta dalam Haryanto, 2012).

Sesuai dengan Rencana Strategis (Renstra) Kementerian Pariwisata dan Ekonomi Kreatif 2010-2014, pembangunan kebudayaan dan kepariwisataan merupakan bagian dari proses pembangunan nasional dalam rangka mencapai cita-cita bangsa Indonesia sebagai bangsa yang mandiri, maju, adil, dan makmur. Pembangunan kebudayaan dan kepariwisataan merupakan rangkaian upaya pembangunan yang berkesinambungan meliputi semua aspek kehidupan masyarakat, bangsa dan negara, untuk melaksanakan tugas mewujudkan tujuan nasional sebagaimana dirumuskan dalam Pembukaan Undang-undang Dasar Negara Republik Indonesia 1945.

Selain itu disebutkan pula pembangunan kepariwisataan memiliki peran penting untuk meningkatkan penyerapan tenaga kerja, mendorongpemerataankesempatanberusaha, mendorong pemerataan pembangunan nasional, dan memberikan kontribusi dalam penerimaan devisa negara yang dihasilkan dari jumlah kunjungan wisatawan serta berperan dalam mengentaskan kemiskinan yang pada akhirnya akan meningkatkan kesejahteraan rakyat. Pariwisata juga berperan dalam upaya meningkatkan jatidiri bangsa dan mendorong kesadaran dan kebanggaan masyarakat terhadap kekayaan alam dan budaya bangsa dan negara dengan memperkenalkan kekayaan alam dan budaya.

\section{Ekowisata}

Definisi ekowisata yang pertama diperkenalkan oleh organisasi The Ecotourism Society (1990) sebagai berikut: ekowisata adalah suatu bentuk perjalanan wisata ke area alami yang dilakukan dengan tujuan mengkonservasi lingkungan dan melestarikan kehidupan dan kesejahteraan penduduk setempat. Semula ekowisata dilakukan oleh wisatawan pecinta alam yang menginginkan di daerah tujuan wisata tetap utuh dan lestari, di samping budaya dan kesejahteraan masyarakatnya tetap terjaga.

Akan tetapi, perkembangannya ternyata bentuk ekowisata ini berkembang karena banyak digemari oleh wisatawan. Wisatawan ingin berkunjung ke area alami, yang dapat menciptakan kegiatan bisnis. Ekowisata kemudian didefinisikan sebagai berikut: bentuk baru dari perjalanan bertanggungjawab ke area alami dan berpetualang yang dapat menciptakan industri pariwisata (Eplerwood, 1999 dalam Fandeli, 2000). Definisi lainnya mengenai ekowisata, seperti yang diuraikan oleh Green Tourism Association, adalah suatu pembangunan pariwisata yang memiliki empat pilar atau atribut sebagai berikut: Pertama, Environmental responsibility; mengandung pengertian proteksi, konservasi atau perluasan sumber daya alam dan lingkungan fisik untuk menjamin kehidupan jangka panjang dan keberlanjutan ekosistem, misalnya wisata alam Ujung Kulon yang akan menghasilkan sebuah konsep ekosistem berkelanjutandarisatwabadakbercula;Kedua, Local economic vitality; mendorong tumbuh dan berkembangnya ekonomi lokal, bisnis dan komunitas untuk menjamin kekuatan ekonomi dan keberlanjutan (sustainability) misalnya dampak dari pembangunan lokasi wisata biasanya akan diikuti oleh maraknya kegiatan ekonomi lokal; Ketiga, Cultural sensitivity; mendorong timbulnya penghormatan dan apresiasi terhadap adat istiadat dan keragaman budaya untuk menjamin kelangsungan budaya lokal yang baik misalnya melalui wisata budaya, maka orang akan mengenal budaya daerah atau negara lain dan menimbulkan penghormatan atas kekayaan budaya tersebut; Keempat, Experiental richness; menciptakan atraksi yang dapat memperkaya dan meningkatkan pengalaman yang lebih memuaskan, melalui partisipasi aktif dalam memahami personal dan keterlibatan dengan alam, manusia, tempat dan/atau budaya (Abdillah, dalam Yoeti, 2006;26). 


\section{Studi Sebelumnya Terkait Dengan Konsep Budaya, Sosial, Lingkungan, dan Pariwisata}

Pengaruh budaya terhadap pariwisata sudah dilakukan sejak tahun 1957 oleh Hanna dengan obyek penelitian pariwisata Bali menggunakan pendekatan kualitatif dengan kesimpulan pariwisata memberikan dampak negatif pada perkembangan budaya Bali di mana nantinya masyarakat Bali diasumsikan tidak lagi mampu membedakan tradisi seni Bali yang sesungguhnya dengan tradisi seni Bali yang sifatnya komersial. Secara keseluruhan pengaruh budaya dan pariwisata dilakukan dengan menggunakan pendekatan kualitatif, dengan beberapa aspek yang dianalisis kontak budaya, manifestasi kebudayaan, revitalisasi budaya, konservasi budaya, degradasi budaya, adaptasi budaya, konflik budaya, dan bauran kebudayaan. Pengaruh modalitas sosial terhadap pariwisata menjadi bahan kajian yang cukup menarik dewasa ini. Beberapa lembaga menjadikan tema tersebut sebagai bahan utama penelitian mereka seperti Center for International Forestry Research ( CIFOR) yang melakukan kajian pembangunan pariwisata berbasis masyarakat di Malinau pada tahun 2004.
Tema modalitas sosial dan pariwisata sebagai salah satu isu terkini yang mereka angkat diantaranya Listiana Afri tahun 2005 mencoba melihat pengaruh Candi Borobudur terhadap perilaku sosial pedagang disekitarnya. Secara keseluruhan penelitian pengaruh modalitas sosial dan pariwisata dilakukan dengan menggunakan pendekatan kualitatif, dengan beberapa aspek yang dianalisis adalah modalitas sosial, konflik sosial, partisipasi lokal, dan sistem sosial. Ketika isu perubahan iklim dan pentingnya daya dukunglingkungan menjadi tema aktual, banyak peneliti kemudian menjadikan penelitian mereka sebagai analisis pengaruh pariwisata dan daya dukung lingkungan diantaranya Gita Alfa Arsyadha tahun 2002 yang melakukan kajian di Pulau Karimunjawa. Secara keseluruhan penelitian pengaruh kondisi lingkungan dan pariwisata dilakukan dengan menggunakan pendekatan kuantitatif, dengan beberapa aspek yang dianalisis adalah daya tampung, daya dukung dengan tujuan mencapai pembangunan berkelanjutan.

Metode analisis, instrumen penelitian dan metode pengumpulan data dapat dilihat pada Tabel 1.

Tabel 1. Hubungan Antara Variabel

\begin{tabular}{|c|c|c|c|c|}
\hline No & Pertanyaan Penelitian & $\begin{array}{c}\text { Pendekatan dan } \\
\text { Instrumen Penelitian }\end{array}$ & Metode Analisis & $\begin{array}{c}\text { Metode Pengumpulan } \\
\text { Data }\end{array}$ \\
\hline 1 & $\begin{array}{l}\text { Nilai-nilai budaya, } \\
\text { sosial dan lingkungan } \\
\text { apa yang mendukung } \\
\text { pengembangan Desa } \\
\text { Wisata di Provinsi } \\
\text { Yogyakarta? }\end{array}$ & $\begin{array}{l}\text { Pendekatan kualitatif } \\
\text { dengan instrumen } \\
\text { penelitian interview } \\
\text { guide terhadap } \\
\text { beberapa stakeholders } \\
\text { terkait. }\end{array}$ & $\begin{array}{l}\text { Menggunakan } \\
\text { metode content } \\
\text { analysis dari } \\
\text { jawaban } \\
\text { informan } \\
\text { penelitian }\end{array}$ & $\begin{array}{l}\text { Wawancara mendalam } \\
\text { (FGD) }\end{array}$ \\
\hline 2 & $\begin{array}{l}\text { Bagaimana } \\
\text { implementasi nilai- } \\
\text { nilai budaya, sosial } \\
\text { dan lingkungan } \\
\text { dalam mendukung } \\
\text { pengembangan Desa } \\
\text { Wisata di Provinsi } \\
\text { Yogyakarta? }\end{array}$ & $\begin{array}{l}\text { Pendekatan kualitatif } \\
\text { dengan instrumen } \\
\text { penelitian interview } \\
\text { guide terhadap } \\
\text { beberapa stakeholders } \\
\text { yang terkait. }\end{array}$ & $\begin{array}{l}\text { Menggunakan } \\
\text { metode content } \\
\text { analysis dari } \\
\text { jawaban } \\
\text { informan } \\
\text { penelitian }\end{array}$ & $\begin{array}{l}\text { Wawancara mendalam } \\
\text { (FGD) }\end{array}$ \\
\hline
\end{tabular}


Tempat yang dipilih sebagai lokasi penelitian adalah Provinsi DIY dengan responden berbagai pelaku budaya, tokoh masyarakat, wisatawan serta pihak-pihak yang terkait dengan kegiatan pengembangan pariwisata berkelanjutan, untuk mendapatkan gambaran mengenai nilai-nilai budaya, sosial, dan kearifan lingkungan yang mendukung pengembangan pariwisata berkelanjutan di. Hasil dari wawancara tersebut digunakan sebagai salah satu dasar penilaian untuk mengevaluasi dan mengkaji pelaksanaan wisata berkelanjutan di Yogyakarta sekaligus konfirmasi kepada wisatawan melalui instrumen kuesioner terstruktur untuk mendapatkan gambaran mengenai persepsi mereka terkait dengan pelaksanaan ekowisata di Yogyakarta sekaligus kesediaan berpartisipasi di dalam pengembangan ekowisata.

Di beberapa Desa Wisata di Kabupaten Sleman dan Kabupaten Bantul yang dianggap menjadi cikal bakal pengembangan Desa Wisata di Provinsi Yogyakarta secara keseluruhan yaitu di Desa Wisata Brayut, Desa Wisata Sambi di Kabupaten Sleman serta Desa Wisata Kebonagung di Kabupaten Bantul.

\section{PEMBAHASAN}

\section{Nilai-nilai budaya, sosial, dan kearifan lingkungan yang mendukung pengembangan Desa Wisata di Provinsi Yogyakarta}

Untuk dapat menjadi maju dan berkelanjutan, masing-masing Desa Wisata tersebut harus mampu melestarikan nilainilai budaya, kearifan lingkungan dan sosial yang bersumber dari falsafah Jawa. Secara lebih khusus, nilai-nilai apa saja yang dikembangkan, berdasarkan hasil diskusi mendalam dengan informan penelitian yang berkompeten, dapat disimpulkan dalam sebuah semboyan yang disebut Sapta Pesona yang terdiri dari Aman, Tertib, Bersih, Sejuk, Indah, Ramah Tamah dan Kenangan. Adapun bentuk implementasi nilai-nilai yang terkandung di dalam Sapta Pesona dengan kekayaan nilai-nilai budaya dan lingkungan adalah sebagai berikut:

\section{Nilai-Nilai Budaya Mencerminkan Keagungan Budaya Jawa Baik Secara Fisik maupun Non-Fisik}

Nilai-nilai budaya fisik Jawa,Keraton sebagai pusat budaya fisik Jawa beserta dengan beberapa bentuk fisik bangunan kuno dan bersejarah lainnya seperti Pasar Beringharjo, Benteng Vasternburg, Taman Sari, serta beberapa bentuk bangunan bersejarah lainnya di Yogyakarta. Beberapa bentuk rumah-rumah penduduk yang masih mengadopsi arsitektur kuno juga dapat digolongkan daya tarik budaya di Yogyakarta. Sementara di Desa Wisata yang menjadi sampel penelitian, indentitas budaya utama muncul lewat rumah-rumah asli penduduk yang masih menggambarkan arsitektur kuno masyarakat Jawa seperti bentuk rumah-rumah Joglo di Desa Wisata Brayut dan beberapa di Kebonagung.

Nilai-nilai budaya Jawa non- fisik, berupa tari-tarian, kesenian karawitan, jathilan, gejog lesung, cokekan, busana khas Jawa serta berbagai jenis makanan dan kuliner khas Jawa seperti apem, gethuk, ondeonde, jadah, cemplon, bakpia, mendoan serta kenduri. Kebiasaan bersepeda onthel juga merupakan salah satu nilai kebudayaan Jawa yang cukup menarik untuk dilestarian.

\section{Nilai-Nilai Kearifan Lingkungan Bersumber dari Falsafah Hidup Masyarakat Jawa}

Falsafah Jawa bahwa manusia itu kedudukannya sederajat dengan alam, saling melengkapi dan saling menghormati. Manusia mengambil makan dari alam sebaliknya alam membutuhkan manusia untuk menjaga dan merawatnya. Secara turun temurun, masyarakat Jawa sudah memiliki nilai-nilai kearifan lingkungan yang biasanya diwujudkan dalam bentuk laranganlarangan simbolik untuk tidak merusak alam dan lingkungan misalnya karena di lokasi tersebut ada penunggunya. Bentuk lain dari nilai-nilai kearifan lingkungan masyarakat Jawa biasanya diwujudkan dalam bentuk jalinan budaya yang juga sifatnya turun temurun antar generasi misalnya dalam 
bentuk berbagai upacara-upacara tradisional yang pada intinya menggambarkan bentuk ucapan puji syukur kepada Tuhan Yang Maha Esa atas segala berkat dan limpahan karunia-Nya sekaligus mengucap syukur kepada alam dan lingkungan sekitar untuk mencegah "kemurkaan".

\section{Nilai-Nilai Kearifan Sosial Bersumber kepada Falsafah Hidup Masyarakat Jawa}

Hasil wawancara dengan Bapak Joyo Martani sebagai pengajar tembang Macapat, pada dasarnya masyarakat Jawa secara turun temurun sudah diatur dan dibekali hidup dengan berbagai bentuk ajaran budi pekerti yang nantinya akan menjadi bekal hidup kelak kemudian hari. Berbagai bentuk pelajaran budi pekerti tersebut dapat dinikmati dari tembang-tembang Macapat yang akan selau dinyanyikan sebagai bentuk pengingat. Secara garis besar dari hasil kesimpulan wawancara dengan beberapa tokoh, nilai-nilai dasar masyarakat Jawa adalah selalu mengutamakan kepentingan bersama, jujur, gotong royong, menghargai sesama, andhap asor, tanpa pamrih, integritas, tanggungjawab, serta dedikasi, loyal, dan perduli dengan sesama serta perduli dengan lingkungan.

\section{Implementasi Nilai-Nilai Budaya, Sosial, dan Lingkungan dalam Mendukung Pengembangan Desa Wisata di Provinsi Yogyakarta}

Secara umum implementasi nilainilai budaya, sosial, dan lingkungan yang mendukung pengembangan Desa Wisata di Provinsi Yogyakarta diwujudkan dalam bentuk atraksi yang disajikan kepada pengunjung. Ada beberapa jenis atraksi yang sifatnya sama di beberapa Desa Wisata tersebut sebagai berikut:

- Homestay atau Ngenger di mana wisatawan akan diajak tinggal dan beraktivitas bersama dengan penduduk di Desa Wisata. Secara umum jenis atraksi ini mencerminkan adanya prinsip pengembangan ekonomi lokal local economic vitality, pengkayaan jenis atraksi (experiental richness), cultural sesnitivity serta environmental responsibility;

- Belajar gamelan atau karawitan, serta menarikan tarian gejog lesung atau selamatan bumi (wiwit) sebagai manifestasi utama pengharapan mendapatkan panen yang melimpah. Secara umum jenis atraksi ini juga mengajarkan prinsip pengembangan ekonomi lokal (local economic vitality), pengkayaan jenis atraksi (experiental richness), (cultural sesnitivity) serta (environmental responsibility).

Di samping jenis atraksi yang sifatnya hampir sama di seluruh Desa Wisata, masing-masing Desa Wisata tentu wajib menyajikan jenis atraksi unggulan yang memang menjadi ciri khas daerah tersebut. Jenis atraksi unggulan ini tentu sangat terkait dengan kondisi alam dan geografis daerah tersebut. Desa Wisata Kebon Agung misalnya secara geografis merupakan daerah pertanian, dengan kelimpahan sungai, dan waduk yang sangat menakjubkan sehingga mereka menjadikan berbagai atraksi yang terkait dengan pertanian sebagai atraksi utama misalnya menanam padi di sawah serta belajar membajak sawah.

Pemilihan lokasi sawah yang akan digunakan sebagai media atraksi juga dilakukan secara musyawarah masyarakat. Prinsip keadilan betul-betul ditegakkan dengan sistem bagi hasil antara pemilik sawah dengan pengelola yang nantinya dibagikan lagi untuk non-pemilik sawah. Karena memiliki infrastruktur waduk yang sangat indah, Desa Wisata Kebon Agung juga mengandalkan berbagai atraksi terkait pemanfaatan waduk tersebut misalnya atraksi perahu naga dengan mengaitkan upacara adat Desa Wisata tersebut sebagai atraksi unggulan.

Atraksi menyulam topi, membuat aneka makanan tradisional, dan membuat janur juga menjadi andalan di Desa Wisata Kebon Agung. Pihak masyarakat yang 
kebetulan rumahnya tidak dipilih sebagai lokasi homestay menjadi penangungjawab utama acara tersebut sekaligus mewujudkan semangat kerjasama dan kekeluargaan antara seluruh lapisan masyarakat desa.

Sebaliknya Desa Wisata Brayut dan Sambi tidak memiliki kekayaan alam dan kondisi geografis sungai seperti Kebon Agung, tetapi mereka memiliki kelebihan pada pengelolaan sektor pertanian, peternakan, keindahan alam pegunungan, pengelolaan jamur kuping, dan pengolahan limbah peternakan menjadi biogas sehingga mereka menjadikan atraksi tersebut sebagai atraksi unggulan.

Desa Wisata Brayut menjadikan pengolahan limbah ternak menjadi biogas sebagai atraksi unggulan daerah tersebut. Para pengunjung nantinya akan diberikan pelajaran bagaimana mengelola limbah ternak dimanfaatkan sebagai sumber energy biogas dan langsung dimanfaatkan sebagai media penerangan jalan di Desa Wisata Brayut. Pengelolaan jamur kuping juga menjadi atraksi lainnya yang cukup mendapat banyak perhatian dari wisatawan.

Konsep ini sebetulnya sangat bermanfaat bukan hanya terkait dengan pengembangan pariwisata itu sendiri, melainkan juga terkait dengan upaya sinergi pengembangan sektor lainnya misalnya sektor pendidikan.

Pengelolaan limbah ternak menjadi biogas serta pengolahan jamur kuping dapat dijadikan media pendidikan berbasis aplikasi dalam mendukung upaya menciptakan generasi mendatang yang lebih perduli dan peka dengan kelestarian lingkungan. Experiental education ini juga dianggap menjadi model pengajaran masa depan yang sangat signifikan.

Hal-hal seperti inilah yang seharusnya menjadi pedoman utama Desa Wisata lainnya terkait penetapan jenis atraksi utama yang akan disajikan yang seharusnya dikembalikan lagi kepada kondisi alam, geografis, dan ciri utama daerah tersebut. Pengembangan ekowisata tidak selalu identik hanya dengan atraksi rafting, flying fox, dan berbagai atraksi modern lainnya yang membutuhkan investasi relatif besar.

\section{SIMPULAN}

Berdasarkan hasil analisis dapat disimpulankan bahwa nilai-nilai yang dapat diterapkan untuk mendukung terciptanya Model Pengembangan Pariwisata Berkelanjutan meliputi: Pertama, Nilai-nilai budaya yang berbentuk fisik seperti rumah adat dan berbagai struktur bangunan lainnya, serta nilai-nilai budaya adat non -fisik seperti tari-tarian, kesenian busana khas adat serta berbagai jenis makanan dan kuliner khas adat masing-masing daerah; Kedua, Nilai-nilai kearifan sosial asli masyarakat yang selalu dilestarikan di masing-masing daerah; Ketiga, Nilai-nilai kearifan lingkungan masyarakat yang mendukung pengembangan pariwisata berkelanjutan seperti sistem pertanian yang menyesuaikan alam dan lingkungan serta beberapa upacara tradisional di masingmasing daerah.

Implementasi nilai-nilai budaya, sosial dan lingkungan di Desa Wisata seharusnya dikaitkan dengan kondisi alam, geografis dan ciri utama daerah tersebut. Dengan demikian daerah tersebut mampu meramu berbagai jenis atraksi yang menjadi kekayaan utama dan ciri khas dalam upaya mendatangkan wisatawan.

\section{DAFTAR PUSTAKA}

Alfa Arsyadha, G., 2002, "Kajian Prospek dan Arahan Pengembangan Atraksi Wisata Kepulauan Karimunjawa Dalam Perspektif Konservasi" Tugas Akhir Jurusan Perencanaan Wilayah dan Kota, Undip.

Arianto, A., 2004, "Upaya Pemerintah Kabupaten Pacitan Dalam Upaya Pelestarian Budaya Cepotran (Studi Kasus Dinas Kebudayaan dan Pariwisata Kabupaten Pacitan)", Skripsi, Jurusan Ilmu Pemerintahan, FISIP, UMM.

Afri, L., 2005, "Pengaruh Obyek Wisata Candi Borobudur Terhadap Perilaku Sosial Ekonomi Pedagang di Kawasan Taman Wisata Candi Borobudur, Kabupaten Magelang", Skripsi, Sarjanan Pendidikan Pacasila dan 
Kewarganegaraan, Universitas Negeri Semarang.

Abimanyu, A., 2010, "Problematika Pariwisata Budaya di Yogyakarta", Sarasehan Budaya, Yogyakarta

Butler, R.W., 1975, "Tourism as An Agent of Social Change, Tourism as a Factor in National and Regional Development",Occasional Paper 4, Peterborough, Ontario Department of Geography, Trent University.

Bukhari, Z., 2005, "StrategiPengembangan Budaya Melayu Unggulan di Kabupaten Bengkalis", Tugas Akhir, Program Studi Manajemen Pembangunan Daerah, Sekolah Pasca Sarjana IPB.

Binarwan, R., 2008, "Pengembangan Pariwisata Berbasis Masyarakat di Obyek Wisata Ciater Jawa Barat", Jurnal Kepariwisataan Indonesia, Departemen Kebudayaan dan Pariwisata Indonesia, vol. 3 No 4 Desember;

Baskoro, dan Cecep R., 2008, "Membangun Kota Pariwisata Berbasis Komunitas; Sebuah Kajian Teoritis" Jurnal Kepariwisataan Indonesia, Departemen Kebudayaan dan Pariwisata Indonesia, vol. 3 No 1 Maret;

Badan Lingkungan Hidup Yogyakarta, 2011, "Isu Lingkungan Strategis dan Rencana Program Pengelolaan Lingkungan Hidup Provinsi DIY", Rakor Regional PPEJ KLH, Yogyakarta;

Baiquni, M., 2009, “Belajar dari Pasang Surut Borobudur dan Konsep Pengembangan Pariwisata Borobudur", Penelitian Fakultas Geografi dan Pusat Studi Pariwisata UGM.

Barika, 2009, "Kajian Dampak Pengembangan Sektor Pariwisata di Kota Bengkulu; Studi Kasus Kawasan Wisata Pantai Panjang dan Tapak Paderi", Tesis, Sekolah Pascasarjana, IPB.
Chaerun N, M., 2008," Pengaruh Aktivitas Pariwisata Terhadap Keberlanjutan Sumberdaya Wisata Pada Obyek Wisata PAI, Kabupaten Tegal", Tugas Akhir Jurusan Perencanaan Wilayah dan Kota, Undip.

Dahles H., 1997, “Urban Tourism and Image Management in Yogyakarta: National Development, Cultural Heritage and the Presentation of a Tourist Product," dalam Gunawan, Myra P., ed., Pariwisata Indonesia: Berbagai Aspek dan Gagasan Pembangunan. hal. 5-28, Bandung: Pusat Penelitian Kepariwisataan Lembaga Penelitian Institut Teknologi Bandung.

Direktorat Jenderal Pariwisata, 1987, Pariwisata Tanah Air Indonesia, Jakarta: Direktorat Jenderal Pariwisata.

Damanik, J., 2006, "Perencanaan Ekowisata; Dari Teori ke Aplikasi" Kerjasama Pusat Studi Pariwisata UGM \& Penerbit Andi, Yogyakarta.

Dirawan, G.D., 2006, "Strategi Pengembangan Ekowisata (Studi Kasus Suaka Margasatwa Mampie Lampoko)" Jurnal Kepariwisataan Indonesia, Jakarta.

Garis-garis Besar Pedoman Pengembangan Ekowisata Indonesia.

Hussein H, M., 2006, "Simbiosis Mutualisme antara Kebudayaan dan Pariwisata", Paper, Seminar Kepariwisataan.

Hasanudin, 2006, "Konflik Kepariwisataan di Padang Pariaman" Draft Artikel Ilmiah Penelitian Dosen Muda Fakultas Sastra Jurusan Sastra Daerah, Universitas Andalas.

Himooned, T., 2007, "Opportunities and Constraint of Local Participation in Ecotourism; Case Study of Kasanka National Park (KNP) Zambia" Tesis in Development Studies Norwegian University of Science and Technology.

Haryanto, J, T., 2012,"Model Pengembangan Pariwisata Berkelanjutan Studi Kasus: 
Desa Wisata di Yogyakarta", Naskah Disertasi, Program Studi Ilmu Lingkungan, Universitas Indonesia.

Ismanto, W., 2008, "Identifikasi Potensi Wediombo Sebagai Kawasan Ekowisata Kars di Kabupaten Gunungkidul, Daerah Istimewa Yogyakarta", Jurnal Kepariwisataan Indonesia, Departemen Kebudayaan dan Pariwisata Indonesia, vol. 3 No 1 Maret;

Irawati, E, R., 2009, "Kajian Perencanaan Penataan Kawasan Wisata Terpadu Pantai Padang (Studi Kasus Penataan Kawasan Pantai Padang-Padang Bay (ity)" Penelitian DIPA Universitas Andalas.

Keraf, dan Sony, 1992, "Etika Lingkungan" Penerbit Kompas, Jakarta.

Kementerian Kebudayaan dan Pariwisata Indonesia, 2004, Rencana Strategis Pembangunan Kebudayaan dan Kepariwisataan Nasional Tahun 20052009: Ringkasan Eksekutif. Jakarta: Kementerian Kebudayaan dan Pariwisata Indonesia.

Karomah, P, Marwati, dan Kapti A., 2007, "Kesiapan Masyarakat Code Untuk Meningkatkan Kecapaka Hidup Dengan Memanfaatkan Limbah Industri Sebagai Cinderamata Khas Yogyakarta", Jurnal Penelitian Bappeda Kota Yogyakarta, No 2 Desember 2007.

Louviere, J. J.; David A. Hensher dan Joffre D. Swait, 2000. Stated Choice Methods: Analysis and Applications. Cambridge: Cambridge University Press.

Lemlit Universitas Terbuka, 2000, "Pengaruh Struktur dan Atraksi Nilai Budaya Lengger Banyumasan Terhadap Peningkatan Industri Pariwisata", Laporan Kajian DIPA Universitas Terbuka.

Lubis, L. A., 2002, "Komunikasi Antar Budaya", USU Digital Library.
Lubis, A. Y., 2009. Epistemologi Fundasional. Jakarta: Akademia

Mc. Kean, P.F., 1973,"Cultural Involution: Tourist Balinese and The Process of Modernization In An Antrpological Perspective", Brown University

Maurer, J.L., 1979, "Tourism and Development in a Socio Cultural Perspective: Indonesia as a Case Study", Geneve Institute, Universitaire d'Estudes du Development.

Malhotra, N., 2004. Marketing Research: An Applied Orientation, Edisi keempat. Pearson Education International.

Mudana, I W., 2005, "Dampak Pariwisata Terhadap Seni Patung Tradisional di Desa Silakarang",Jurnal Pariwisata, Universitas Udayana.

Mualisin, I., 2007, "Model Pengembangan Pariwisata Berbasis Masyarakat di Kota Yogyakarta", Jurnal Penelitian Bappeda Kota Yogyakarta No 2 Desember 2007.

Muda, S. M., 2008, "Ekspansi Budaya; Lepas Landas Kebudayaan Indonesia", Jurnal Kebudayaan volume 2 Agustus 2008, Kementrian Budaya dan Pariwisata Indonesia.

Muriawan Putra, A., 2009, "Sosialisasi Konsep Pariwisata Berkelanjutan Dalam Pengelolaan Obyek Wisata Pantai Yeh Gangga, Kabupaten Tabanan", Tugas Akhir Program Studi Pariwisata Universitas Udayana.

Nirwandar, S., 2005. Pembangunan Pariwisata di Era Otonomi Daerah. Bappenas.

Neraca Satelit Pariwisata Nasional (NESPARNAS) 2009, Pusat Pengelolaan Data dan Sistem Jaringan, Departemen Kebudayaan dan Pariwisata Indonesia

Pariwisata Indonesia: Berbagai Aspek dan Gagasan Pembangunan. Bandung: Pusat Penelitian Kepariwisataan Lembaga Penelitian Institut Teknologi Bandung. 
Pardosi, J, 2002, "Revitalisasi Kebudayaan Batak Toba Dalam Pengembangan Pariwisata di Kabupaten Toba Samosir: Studi Kasus Seni Pertunjukan Tortor dan Gondang Sabangunan di Huta Bolon Simanindo", Tesis, Program Studi Magister Kajian Budaya, Universitas Udayana.

Pendit, S. N., 2003, "Ilmu Pariwisata, Sebuah Pengantar Perdana" PT. Pradnya Paramita, Jakarta.

Picard, M, 2006,"Bali; Pariwisata Budaya dan Budaya Pariwisata" Kepustakaan Populer Gramedia, Forum JakartaParis, Jakarta.

Pitana, I Gde \& Putu G. G., 2009. Sosiologi Pariwisata.Penerbit Andi Yogyakarta.

Pitana, I Gde, dan I Ketut, S, D., 2009, "Pengantar Ilmu Pariwisata", Penerbit Andi, Yogyakarta.

Peraturan Walikota Yogyakarta Nomor 88 Tahun 2009 Tentang Penjabaran Status Kawasan, Pemanfaatan Lahan Intensitas Pemanfaatan Ruang.
Ritchie, J.R and Zins, 1978, "Culture as a Determinant of The Attractivenes of Tourist Region", Annals of Tourism Research.

Rejeki, Ikeu Sri, 2005, "Analisis Permintaan Manfaat Jasa Lingkungan Taman Nasional Gunung Gede Pangrango: Perbandingan Antara Metoda Biaya Perjalanan dan Metoda Valuasi Kontingensi." Tesis untuk meraih gelar Magister Sains Ekonomi Program Pascasarjana Ilmu Ekonomi Fakultas Ekonomi Universitas Indonesia, Depok.

Rahajeng, A, 2008," Analisis Faktor Keputusan Wisata Budaya; Sejarah dan Alam Yogyakarta: Persepsi Wisatawan Domestik", Jurnal Ekonomi Pembangunan hal 33-49;

Samad, N, 1997," Culture Shock Dalam Industri Pariwisata",Jurnal Penelitian dan Karya Ilmiah, Pusat Penelitian Akademi Pariwisata Trisakti.

Sammeng, A. M., 2000, "Cakrawala Pariwisata" Jakarta. 